\title{
In Silico Screening of Schleichera oleosa Phytocompounds as Estrogen Receptors Alpha Inhibitors for Breast Cancer
}

\author{
Radita Intan Aisyah Pratiwi ${ }^{1}$, Tintrim Rahayu ${ }^{1}$, Nurul Jadid Mubarakati ${ }^{1}$ \\ ${ }^{1}$ Department of Biology, Faculty of Mathematic and Natural Sciences, Islamic University of Malang, Jl. Mayjen Haryono Gg. 10 No.193 \\ Malang, 65144, Indonesia
}

Submission: October 2020; Revised: October 2020; Accepted: November 2020

*Corresponding author: tintrim.rahayu@unisma.ac.id ; nurul.jadid@unisma.ac.id ; Tel : +62-8986307836

\begin{abstract}
Abstrak: This study aimed to predict the potential activity, toxicity, and interaction of fifteen bioactive compounds from Schleichera oleosa as estrogen receptor alpha inhibitors via in silico analysis. The active compound was downloaded from the PubChem database. The 3D structure of the human estrogen receptor alpha (ER $\alpha$ ) was obtained from the Protein Data Bank database with 4-Hydroxytamoxyfen as a positive control. The interaction of bioactive compounds with macromolecule was examined via a molecular specific docking using AutoDock Vina with PyRx 9.5 software. The protein was visualized using Discovery Studio 4.1. The drug-likeness property and human intestinal absorption of those fifteen bioactive compounds were evaluated through absorption, distribution, metabolism, and excretion (ADME) analysis using the pkCSM online tool program. The interactions between proteins and ligands are largely through the formation of hydrogen and van der Waals bonds. The binding energy of lupeol acetate, lupeol, schleicheol 1, betulinic acid, betulin, beta-sitosterol, schleicherastatin 7, schleicherastatin 2, schleicherastatin 4, scopoletin, schleicherastatin 3, schleicherastatin 1, schleicherastatin 6, schleicherastatin 5 alpha and schleicherastatin receptors including -8.3, -8.3, -7.1, -7.1, -6.7, -6.6, -6.6, -6.5, -6.5, -6.3, -6.2, -6.2 -6.1, -5.9 and -5.5 kcal / mol, respectively. The in silico ADME analysis also revealed that lupeol and lupeol acetate were the best active compounds that pass the test based on the Lipinski rule, ADME, and toxicity. Therefore, it can be stated that Schleichera oleosa has potential as an inhibitor of alpha estrogen receptors. The inhibitory activity of alpha estrogen receptors has led to new breakthroughs in plant-based medicinal products, particularly for breast cancer.
\end{abstract}

Keyword: Schleichera oleosa, alpha estrogen receptors, phytocompound, breast cancer and in silico

\section{INTRODUCTION}

Breast cancer is a malignancy in breast tissue that originates from the epithelium of the ducts and lobules. Breast cancer is one of the common cancer in Indonesia. Based on GLOBOCAN data, the International Agency for Research on Cancer (IARC), in 2018 there were 2,088,844 cases of breast cancer and it was the highest cancer case that occurred in women with a percentage of $24.2 \%$ [6]. Overexpression of estrogen receptors alpha (ER $\alpha)$ causes the formation and development of breast cancer cells. Two receptors mediate the biological action of the hormone estrogen, estrogen receptors alpha (ER $\alpha)$ and estrogen receptors Beta (ER $\beta)$, which regulate transcription factors [11]. The ER $\alpha$ has a stronger to bind estrogen than ER $\beta$. According to Liao et al. (2014) high expression of ER $\alpha$ correlate with breast cancer cell proliferation. Estrogen from breast tissue bind to ER $\alpha$ and trigger cancer cell proliferation. Therefore, it is necessary to develop a natural compound that has the potential to inhibit $\mathrm{ER} \alpha$ activity.

Schleichera oleosa or Kesambi is a plant belonging to the Sapindaceae family, is found in
Madura. Schleichera oleosa contains active compounds that has good pharmacological potential, such as an anticancer [9]. Thus, a further approach is needed to determine the potential of these plants, considering that Schleichera oleosa's research is still rarely done. An early approach that can be used is the computational test using molecular docking. Molecular docking is done to limit side effects and increase breast cancer chemotherapy's effectiveness using a type of drug that can work on molecular targets. The 4-hydroxitamoxifen is the first-line drug therapy in breast cancer progression. Therefore, this study focused on molecular docking tests to determine the mechanism of action against the Era. The tested compounds are expected to have the potential to be developed as therapeutic drugs against breast cancer.

\section{METHODS}

\section{Compound Preparation}

The active compounds used are scopoletin, betasitosterol, lupeol, lupeol acetate, botulin, betulinic acid, schleicheol 1, schleicheol 2, schleicherastatin 1, schleicherastatin 2, schleicherastatin 3, 
schleicherastatin $\quad 4, \quad$ schleicherastatin 5 , schleicherastatin 6 and schleicherastatin 7. 4hidroxitamoxifen was used as a positive control. Active compound preparations were downloaded from the National Center for Biotechnology Information (NCBI) Pubchem database (http://PubChem.ncbi.nlm.nih.gov) and the file format was changed by changing the sdf format to the pdb format. using Chimera 1.14.

\section{Docking Active Compounds with 3ERT Protein}

Estrogen receptor alpha as target proteins was obtained from the Research Collaboratory for Structural Bioinformatics (RCSB) Protein Data Bank with PDB ID: 3ERT (http://www.rcsb.org/pdb). Furthermore, 3ERT protein and native ligand were separated by the Chimera 1.14 program. The native ligand, active compounds, and 3ERT protein were docked using the PyRx program. The docking results visualized $2 \mathrm{D}$ and $3 \mathrm{D}$ views using the Discovery Studio Visualizer 4.1 program.

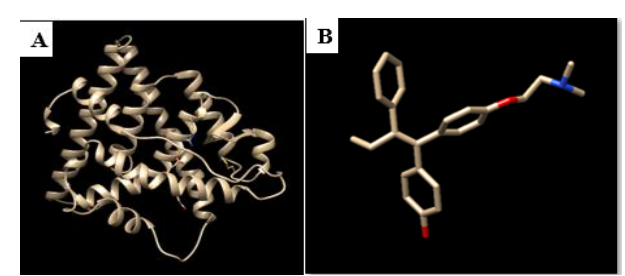

Figure 1. (A) 3ERT protein structure and (B) native ligand that has separated from the protein

Prediction of Physicochemical, Pharmacokinetic, and Toxicity of Compounds
Tracking molecular weight (BM), the logarithm of the octanol/water partition coefficient ( $\log \mathrm{P})$, Hydrogen Bond Acceptors (HBA), Hydrogen Bond Donors (HBD), and molar refractivity were carried out using the Lipinski Rule of Five program (http: //www.scfbioiitd.res.in/software/drugdesign/lipinski.j sp). The search is done by entering the active compound file in pdb format then submitting it. The ADME and compound toxicity was carried out using the pkCSM online tool program (http://biosig.unimelb.edu.au/pkcsm/predic-tion) by entering the SMILES code of each active compound

\section{RESULTS AND DISCUSSIONS}

The prediction of Lipinski's five rules of active compounds are shown in Table 1. According to Lipinski's rules, several properties need to be considered before doing molecular docking, involving the molecular weight of the tested compound is not more than $500 \mathrm{~g} / \mathrm{mol}$, the hydrogendonor is not more than five, and the hydrogenacceptor is less than ten, so that the drug can penetrate the cell membrane to reach its target receptors. A molecular weight that is too large will find it difficult to penetrate the cell membrane because it can interfere with the diffusion process. The drug's low molecular weight indicated the drug easier to diffuse to the cell membrane $[3,8]$. Likewise, the $\mathrm{H}$-donor and $\mathrm{H}$-acceptor values that are too large will make more hydrogen bonds formed, which slows down the drug to reach its target [10].

Tabel 1. Lipinski Five of Rule Test Results

\begin{tabular}{llccccc}
\hline No. & Active Compound & $\begin{array}{c}\text { Molecular Weight } \\
\text { (gram/mol) }\end{array}$ & $\begin{array}{c}\mathrm{H}- \\
\text { Donor }\end{array}$ & $\begin{array}{c}\mathrm{H}- \\
\text { Acceptor }\end{array}$ & Log-P & Molar Refractivity \\
\hline 1 & 4-Hydroxytamoxyfen & 387.5 & 1 & 3 & 5.70 & 121.246 \\
2 & Scopoletin & 192.7 & 1 & 4 & 1.33 & 49.32 \\
3 & Beta-Sitosterol & 414.7 & 1 & 1 & 8.02 & 128.21 \\
4 & Betulin & 442.7 & 2 & 2 & 6.99 & 132.061 \\
5 & Betulinic Acid & 456.7 & 2 & 3 & 7.08 & 132.61 \\
6 & Lupeol & 426.7 & 1 & 1 & 8.02 & 130.64 \\
7 & Lupeol Acetat & 468.7 & 0 & 2 & 8.59 & 140.19 \\
8 & Schleicheol 1 & 444.7 & 1 & 2 & 7.64 & 134.39 \\
9 & Schleicheol 2 & 444.7 & 1 & 2 & 7.64 & 134.39 \\
10 & Schleicherastatin 1 & 460.7 & 2 & 3 & 6.62 & 135.78 \\
11 & Schleicherastatin 2 & 460.7 & 2 & 3 & 6.62 & 135.78 \\
12 & Schleicherastatin 3 & 446.7 & 1 & 3 & 7.34 & 150.84 \\
13 & Schleicherastatin 4 & 446.7 & 2 & 3 & 6.23 & 131.16 \\
14 & Schleicherastatin 5 & 444.7 & 2 & 3 & 6.17 & 129.99 \\
15 & Schleicherastatin 6 & 430.7 & 2 & 3 & 5.78 & 125.37 \\
16 & Schleicherastatin 7 & 430.7 & 2 & 3 & 5.78 & 125.37 \\
\hline
\end{tabular}

According to Lipinski's rule, the ligands should have molecular weight $<500 \mathrm{Da}$, Log-P value $<5$, donor hydrogen bond $<5$. Acceptor hydrogen bonds $<10$ and molar refractivity between 40-130.
Compounds are high permeability when they have two or more Lipinski criteria $[1,4]$. The fifteen compounds showed more than two Lipinski criteria. Meanwhile, scopoletin is the only compound that 
proved all Lipinski criteria. Apart from Lipinski's rule, active compounds were predicted their pharmacokinetic properties and toxicity using the pkCSM online tool program, which the results were described in Table 2.

The Absortion, Distribution, Metabolism ad Excretion (ADME) properties, and toxicity tests were carried out using the pkCSM online tool. Prediction of drug absorption was assessed based on the drug's ability to absorb in the intestine and permeability in $\mathrm{CaCo} 2$ cells. A compound is said to have a good absorption value if the Intestinal Absorption Human value is $>80 \%$ and bad if $<30 \%$ [2]. All compounds revealed well absorbed in the intestine with ranges from 93.408 - 97.894\%. The single-layer cell permeability of $\mathrm{CaCo} 2(\mathrm{CaCo} 2 \mathrm{Cell}$ Monolayer Permeability) is often used as an in vitro model of the intestinal mucosa to predict the absorption of drugs given orally. The Log-P value is high if it has a value $>0.90$. All the compounds were more than 0.90, indicating good permeability in $\mathrm{CaCo} 2$ cells [12].

Table 2. Absorption, Distribution, Metabolism ad Excretion (ADME) and Toxicity Test Results

\begin{tabular}{|c|c|c|c|c|c|c|c|c|c|c|c|}
\hline \multirow[b]{2}{*}{ No } & \multirow[b]{2}{*}{ Active Compound } & \multicolumn{2}{|c|}{ Absorption } & \multirow{2}{*}{$\begin{array}{l}\text { Distribution } \\
\text { VDSS BBB }\end{array}$} & \multicolumn{2}{|c|}{ Metabolism } & \multicolumn{2}{|c|}{ Excretion } & \multicolumn{2}{|c|}{ Toxicity } & \multirow[b]{2}{*}{ y Hepatoxicity } \\
\hline & & $\begin{array}{l}\text { Intestinal } \\
\text { Absorbtion } \\
\text { Human (\%) }\end{array}$ & $\begin{array}{l}\mathrm{CaCO}_{2} \\
\text { Permeability } \\
\left(10^{-6} \mathrm{~cm} / \mathrm{s}\right)\end{array}$ & & $\begin{array}{l}\text { CYP2D6 } \\
\text { substrate }\end{array}$ & $\begin{array}{l}\text { CYP2D } \\
\text { inhibitor }\end{array}$ & $\begin{array}{l}6 \text { Total } \\
\mathrm{r} \text { clearance }\end{array}$ & $\begin{array}{l}\text { Renal } \\
\text { OCT2 } \\
\text { substrate }\end{array}$ & $\begin{array}{l}\text { LD50 } \\
(\mathrm{mol} / \\
\mathrm{kg})\end{array}$ & $\begin{array}{l}\text { AMES } \\
\text { Toxicity }\end{array}$ & \\
\hline 1 & 4-Hydroxitamoxyfen & 94.564 & 1.026 & $0.266-0.307$ & No & Yes & 0.54 & No 2 & 2.278 & No & No \\
\hline 2 & Scopoletin & 95.277 & 1.184 & $0.034 \quad-0.299$ & No & No & 0.73 & No & 1.950 & No & No \\
\hline 3 & Beta-sitosterol & 94.464 & 1.201 & $0.193 \quad 0.781$ & No & No & 0.628 & No & 2.552 & No & No \\
\hline 4 & Lupeol & 95.782 & 1.226 & $0 \quad 0.726$ & No & No & 0.153 & No & 2.563 & No & No \\
\hline 5 & Lupeol asetat & 97.894 & 1.221 & -0.120 .644 & No & No & 0.06 & No & 2.512 & No & No \\
\hline 6 & Betulin & 94.539 & 1.201 & $-0.177-0.295$ & No & No & 0.236 & No & 2.699 & No & No \\
\hline 7 & Betulinic Acid & 94.539 & 1.176 & $-0.177-0.295$ & No & No & 0.236 & No & 2.699 & No & Yes \\
\hline 8 & Schleicheol 1 & 95.26 & 1.184 & $0.036 \quad 0.75$ & No & No & 0.683 & No & 2.554 & No & No \\
\hline 9 & Schleicheol 2 & 95.26 & 1.184 & $0.036 \quad 0.75$ & No & No & 0.683 & No & 2.594 & No & No \\
\hline 10 & Schleicherastatin 1 & 94.469 & 1.176 & $-0.023-0.544$ & No & No & 0.716 & No & 2.851 & No & No \\
\hline 11 & Schleicherastatin 2 & 94.469 & 1.176 & $-0.023-0.544$ & No & No & 0.716 & No & 2.851 & No & No \\
\hline 12 & Schleicherastatin 3 & 93.408 & 1.174 & $0.14 \quad-0.319$ & No & No & 0.659 & No & 2.141 & No & No \\
\hline 13 & Schleicherastatin 4 & 93.408 & 1.174 & $0.14 \quad-0.319$ & No & No & 0.659 & No & 2.141 & No & No \\
\hline 14 & Schleicherastatin 5 & 94.802 & 1.277 & $-0.236-0.606$ & No & No & 0.608 & No & 2.926 & No & No \\
\hline 15 & Schleicherastatin 6 & 93.741 & 1.276 & $-0.051-0.381$ & No & No & 0.551 & No & 2.191 & No & No \\
\hline 16 & Schleicherastatin 7 & 93.741 & 1.276 & $-0.051-0.381$ & No & No & 0.551 & No & 2.191 & No & No \\
\hline
\end{tabular}

According to Pires et al. (2015), the total drug dose volume of distribution at steady state (VDSS) is a distributed dose-volume to provide the same concentration as in blood plasma. Compounds are categorized as low volume distribution if the Log VDSS is less than -0.15 , moderate $(-0.15>$ VDSS $<0.45$ ), and high $\log$ VDSS $>0.45$. The compounds with low VDSS values are betulinic acid, botulin, and schleicherastatin 5 , with values -0.177 to -0.236 . Scopoletin, beta-sitosterol, lupeol, Lupeol acetate, schleicheol 1, schleicheol 2, schleicherastatin 1 schleicherastatin 2, schleicherastatin 3, schleicherastatin 4 schleicherastatin 6 and schleicherastatin 7 were moderate ( -0.12 to 0.266$)$.

The next parameter that needs to be considered is drugs' ability to cross the blood-brain barrier (BBB) to reduce side effects and toxicity and increase the efficacy of drugs whose pharmacological activity is in the brain. Compounds will penetrate the bloodbrain barrier well if they have a $\log \mathrm{BB}$ value $>0,3$ and cannot be distributed appropriately if $\log \mathrm{BB}<-1$ [12]. Beta-sitosterol, lupeol, lupeol acetate, schleicheol 1, and schleicheol 2 can penetrate the blood brain barrier well because they have a $\log$ $\mathrm{BB}>0.3$ which ranges from 0.726 to 0.781 . While the compounds of scopoletin, betulin, betulinic acid, schleicherastatin 1, schleicherastatin 2, schleicherastatin 3, schleicherastatin 4, schleicherastatin 5, schleicherastatin 6, and schleicherastatin 7 have $\log$ BB values between 0.295 to -0.606 that suggested low ability to cross the blood-brain barrier. Cytochrome P450 is an important detoxification enzyme in the body, mainly found in the liver. Cytochrome P450 oxidized foreign organic compounds, including drugs, and facilitated the excretion of these compounds. These enzyme inhibitors, such as grapefruit juice, can affect drug metabolism and are therefore contraindicated against cytochrome P450 enzymes. Therefore, it is crucial to assess the compound's activity to inhibit cytochrome $\mathrm{P} 450$, which in this study is represented by the cytochrome P2D6 isoform (CYP2D6). From the table above, it can be seen that all active compounds do not affect or inhibit the CYP2D6 enzyme, so it can be predicted that these derivative compounds tend to be metabolized by the P450 enzyme [12]. 
1. 4-Hydroxitamoxifen-Human estrogen receptor alpha

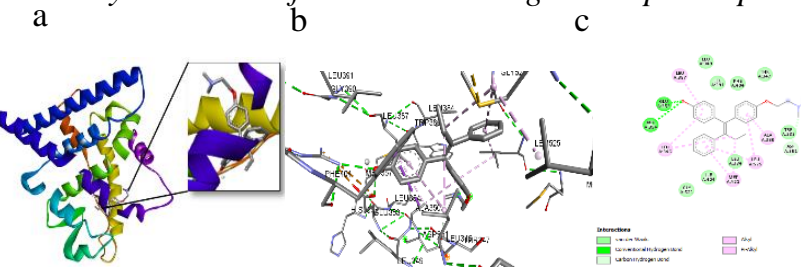

3. Beta-sitosterol-Human estrogen receptor alpha

a

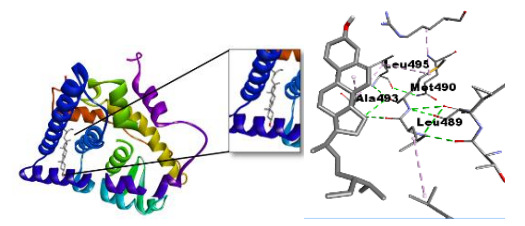

5. Betulinic acid-Human estrogen receptor alpha a $\mathrm{b}$

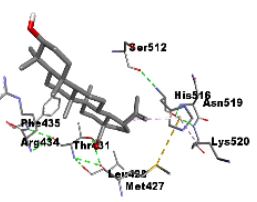

7. Lupeol acetate-Human estrogen receptor alpha

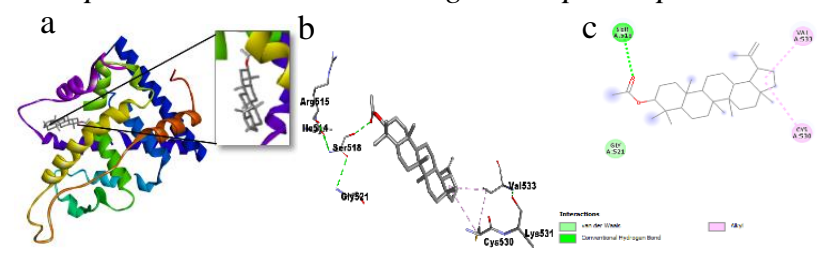

9. Schleicheol 2-Human estrogen receptor alpha

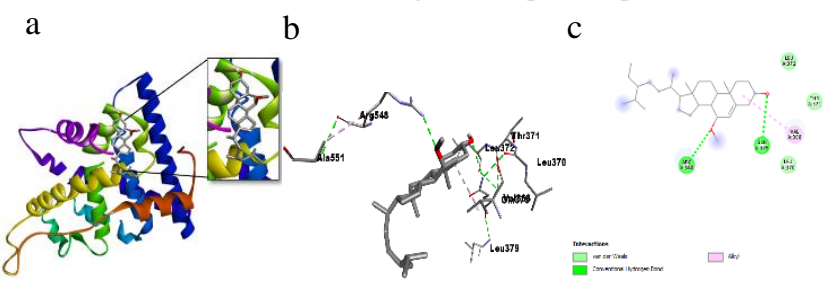

11. Schleicherastatin 2-Human estrogen receptor alpha

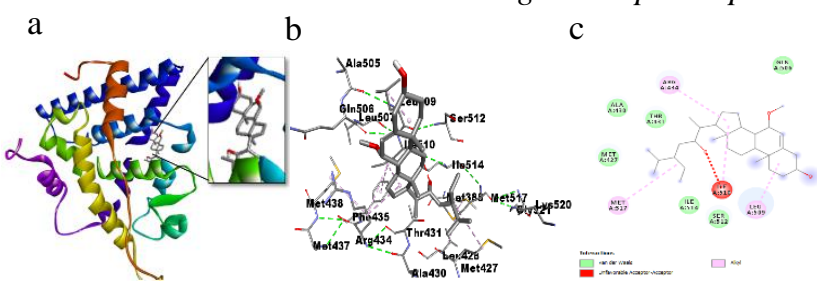

13. Schleicherastatin 4-Human estrogen receptor alpha

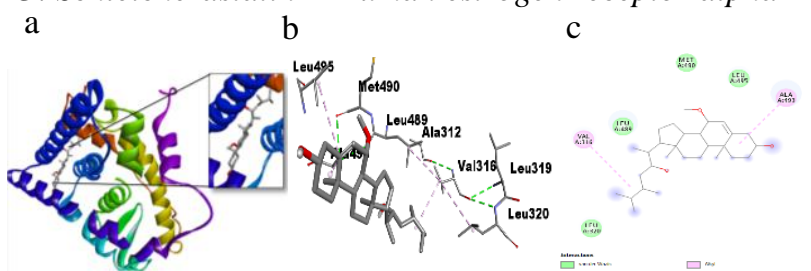

15. Schleicherastatin 6-Human estrogen receptor alpha
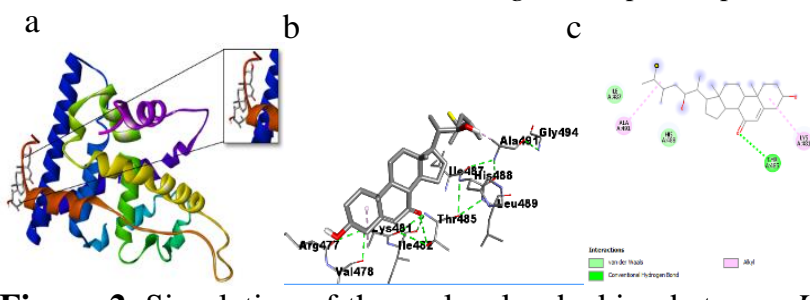

2. Scopoletin-Human estrogen receptor alpha

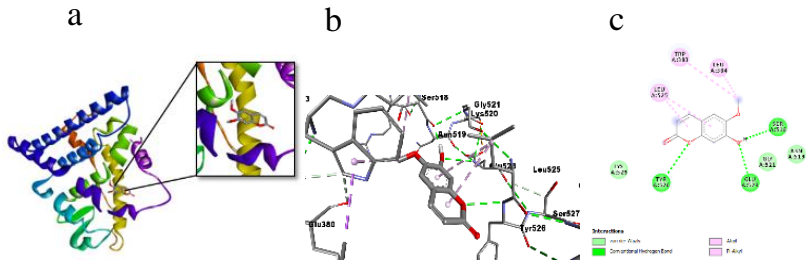

4. Betulin-Human estrogen receptor alpha

a b c c

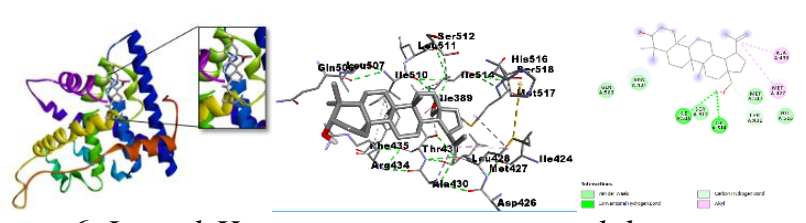

6. Lupeol-Human estrogen receptor alpha

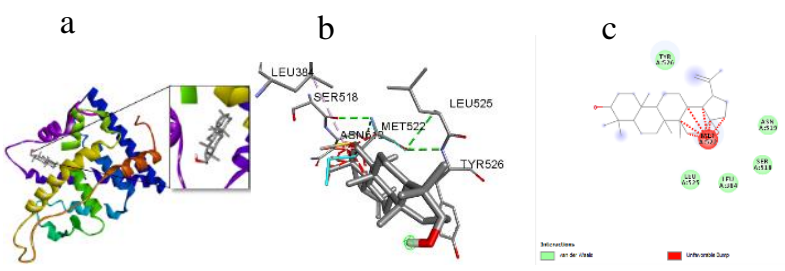

8. Schleicheol 1-Human estrogen receptor alpha

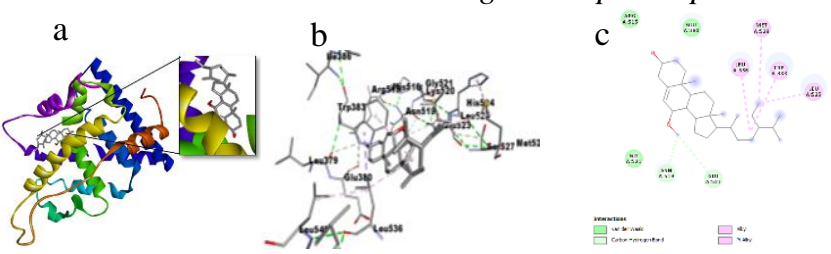

10. Schleicherastatin 1-Human estrogen receptor alpha

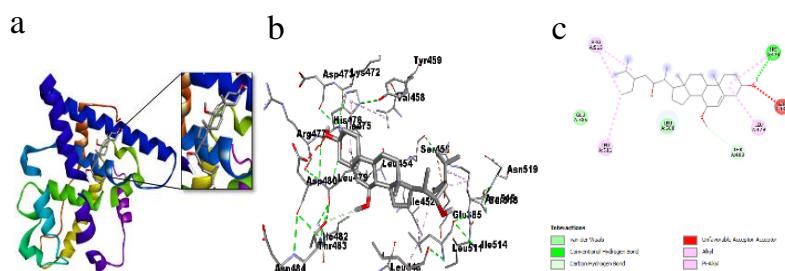

12. Schleicherastatin 3-Human estrogen receptor alpha

a

$\mathrm{b}$

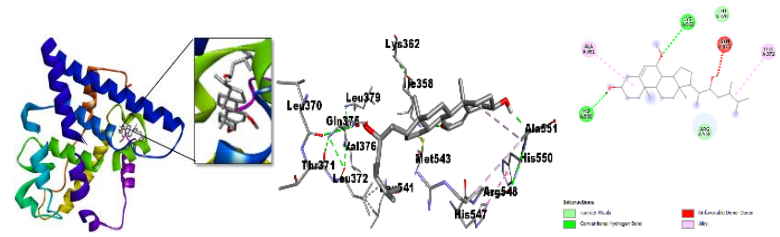

14. Schleicherastatin 5-Human estrogen receptor alpha

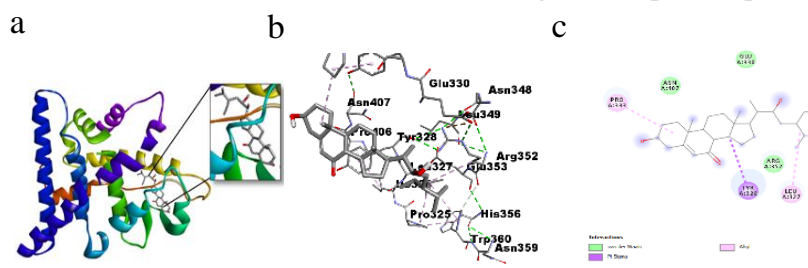

16. Schleicherastatin 7-Human estrogen receptor alpha a

$\mathrm{b}$

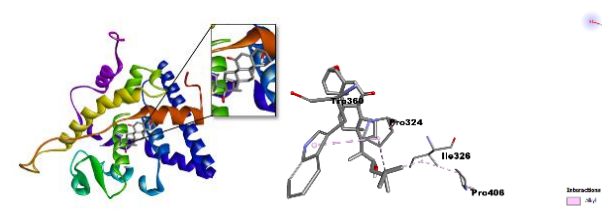

Figure 2. Simulation of the molecular docking between Human estrogen receptor alpha (PDB ID: 3ERT) with Kesamben compound (a) Protein-ligand complexes; (b) 3D structure interactions; and (c) The 2D structures interaction 
Total Clearance (CLTOT) constant and the Renal Organic Cation Transporter 2 (OCT2) were a combination of hepatic clearance (metabolism in the liver and bile) and renal clearance (excretion through the kidneys) to predict the excretion process, bioavailability and to determine the dose level to reach a steady-state concentration [5]. Table 2 revealed the active compound of Kesambi ranges from 0.06 to $0.73 \log \mathrm{mg} / \mathrm{kg} / \mathrm{day}$, suggesting the rate of excretion of the compound can be predicted. However, Kesambi compounds did not have any effect on the OCT2 substrate. Organic Cation Transporter 2 (OCT2) is a transporter in the kidneys which plays an essential role in the disposition and clearance of drugs and endogenous compounds. OCT2 substrates also have the potential to cause side interactions when given together with OCT2 inhibitors.

The prediction of oral rat acute toxicity (LD50) and compound toxicity classification of Kesambi compounds were described in Table 2. The LD50 is the amount of a given compound that caused $50 \%$ of the experimental animal death. The compounds ranged from 2,141 to 2,926, classified to 5th class as a low acute toxicity effect. Scopoletin showed LD50 1,950 that are 4th class category as dangerous if swallowed. The Ames toxicity test shows that all compounds are not mutagenic. Meanwhile, the hepatoxicity test shows that all compounds are not toxic to the liver except Betulinic acid.

Molecular docking was used for screening of fifteen active compounds to inhibit human estrogen receptor alpha protein. The binding sites of the 15 compounds were shown in Figure 2. Molecular docking results showed the value of the bond energy obtained, the interaction with the amino acid residues with various types of bonds. The bond values of the fifteen active compounds tested and the amino acids can be seen in Table 3. Table 3 demonstrated that all compounds were active [12]. Fifteen amino acid residues interacted with 4-Hidroxytamoxifen, ARG394 and GLU353 with conventional hydrogen bonds. Carbon hydrogen bonds at amino acid residues THR347, LEU349, TRP383, LEU384, LEU391, PHE404, ILE424 \& GLY521. The binding affinity value is $-9.6 \mathrm{kcal} / \mathrm{mol}$. Van der Waals in ASP351 and alkyl interactions with LEU346, ALA350, LEU387, MET421 \& LEU525 through hydrophobic bonds. The binding affinity value obtained is $-9.3 \mathrm{kcal} / \mathrm{mol}$.

Lupeol acetate bound to four amino acid residues of human estrogen receptor-alpha. There were SER518 with conventional hydrogen bonds, GLY521 with Van der Waals bond, and alkyl interaction with CYS530 and VAL533 through hydrophobic bonds. The binding affinity value obtained is $-8.3 \mathrm{kcal} / \mathrm{mol}$. Lupeol is bound to five amino acid residues, namely van der Waals with
GLY521 SER518, AS519, LEU525, TYR526, and LEU384 and also the unfavorable bump bond with MET522. The binding affinity value obtained is -8.3 $\mathrm{kcal} / \mathrm{mol}$.

Schleicheol 1 forms bonds with nine amino acid residues. The bonds formed are carbon-hydrogen bonds with ASN519 and GLU523. Van der Waals bond with ARG515, GLY531 and GLU530 and alkyl interactions with TRP383, MET528, LEU525 and LEU536 through hydrophobic bonds. The binding affinity value obtained is $-7.1 \mathrm{kcal} / \mathrm{mol}$.

Betulinic acid forms bonds with five amino acid residues. The bond formed is in the form of a conventional hydrogen bond with the amino acid THR431 van der Waals bond with MET427, ARG434 and SER512 and alkyl interaction with HIS516 through hydrophobic bonds. The bond energy value obtained is $-7.1 \mathrm{kcal} / \mathrm{mol}$.

Betulin is bound to nine amino acid residues. The bonds formed are conventional hydrogen bonds with amino acids ILE510 and ILE514 and carbonhydrogen bonds with amino acid THR431. Van der Waals bonds with ARG434, GLN506, SER512, HIS516 and MET517 and alkyl interactions with MET427 and ALA430 through hydrophobic bonds. While the bond energy value obtained is -6.7 $\mathrm{kcal} / \mathrm{mol}$.

Beta-sitosterol is bound to four amino acid residues. The bonds formed are van der Waals bonds with VAL316, LEU489, MET490, LEU495 and ARG503 and alkyl interactions with ALA493 through hydrophobic bonds. The bond energy value obtained is $-6.6 \mathrm{kcal} / \mathrm{mol}$. Schleicherastatin 7 forms bonds with only two amino acid residues. The bond is in the form of alkyl interaction with PRO324 \& ILE326. The binding affinity value obtained is $-6.6 \mathrm{kcal} / \mathrm{mol}$.

Schleicherastatin 2 forms bonds with nine amino acid residues. The bonds formed are van der Waals bonds with MET427, ALA430, THR431, GLN506, SER512, and ILE514 and alkyl interactions LEU509 and MET517 through hydrophobic bonds. There is also an unfortunate bond with ILE510. The binding affinity value obtained is $-6.5 \mathrm{kcal} / \mathrm{mol}$.

Schleicherastatin 4 forms bonds with six amino acid residues. The bonds formed are van der Waals bonds with LEU320, LEU489, MET490, and LEU495 and Alkyl interactions with VAL316 and ALA493 through hydrophobic bonds. There is also an unfortunate bond with ILE510. The binding affinity value obtained is $-6.5 \mathrm{kcal} / \mathrm{mol}$. Scopoletin showed seven binding sites toward human estrogen receptoralpha, THR347 as conventional hydrogen bond, ASN519, GLY521 and LYS529 by Van der Waals, TRP383, LEU384, and LEU525 through hydrophobic bonds. The binding affinity value obtained is -6.3 $\mathrm{kcal} / \mathrm{mol}$. 
Table 3. Molecular Docking Test Result

\begin{tabular}{|c|c|c|c|c|}
\hline No. & Active Compound & $\begin{array}{l}\text { Binding } \\
\text { Affinity } \\
(\mathrm{kcal} / \mathrm{mol}) \\
\end{array}$ & Bounded Amino Acids & Type of Bond \\
\hline 1. & 4-Hydroxitamoxiven & -9.6 & $\begin{array}{ll}\text { - } & \text { ARG394 \& GLU353 } \\
\text { - } & \text { THR347, LEU349, TRP383, } \\
& \text { LEU384, LEU391, PHE404, } \\
& \text { ILE424 \& GLY521 } \\
\text { - } & \text { ASP351 } \\
- & \text { LEU346, ALA350, LEU387, } \\
& \text { MET421 \& LEU525 }\end{array}$ & $\begin{array}{l}\text { - Conventional Hydrogen Bond } \\
\text { - Carbon Hydrogen Bond } \\
\text { - Van der Waals Bond } \\
\text { - Alkil }\end{array}$ \\
\hline 2. & Lupeol asetat & -8.3 & $\begin{array}{l}\text { - SER518 } \\
\text { - GLY521 } \\
\text { - CYS530 \& VAL533 } \\
\end{array}$ & $\begin{array}{l}\text { - Conventional Hydrogen Bond } \\
\text { - Van der Waals Bond } \\
\text { - Alkil }\end{array}$ \\
\hline 3. & Lupeol & -8.3 & $\begin{array}{l}\text { - LEU384, SER518, ASN519, } \\
\text { LEU525 \& TYR526 } \\
\text { - MET522 }\end{array}$ & $\begin{array}{l}\text { - Van der Waals Bond } \\
\text { - Unfavorable Bump }\end{array}$ \\
\hline 4. & Schleicheol 1 & -7.1 & $\begin{array}{l}\text { - ASN519 \& GLU523 } \\
\text { - GLU380, ARG515 \& GLY521 } \\
\text { - TRP383, LEU525, MET528 \& } \\
\text { LEU536 }\end{array}$ & $\begin{array}{l}\text { - Conventional Hydrogen Bond } \\
\text { - Van der Waals Bond } \\
\text { - Alkil }\end{array}$ \\
\hline 5. & Betulinic acid & -7.1 & $\begin{array}{l}\text { - } \text { THR431 } \\
\text { - MET427, ARG434 \& SER512 } \\
\text { - HIS516 }\end{array}$ & $\begin{array}{l}\text { - Conventional Hydrogen Bond } \\
\text { - Van der Waals Bond } \\
\text { - Alkil }\end{array}$ \\
\hline 6. & Betulin & -6.7 & $\begin{array}{l}\text { - } \text { ILE510 \& ILE514 } \\
\text { - THR431 } \\
\text { - ARG434, GLN506, SER512, } \\
\text { HIS516 \& MET517 } \\
\text { - } \text { MET } 427 \text { \& ALA430 }\end{array}$ & $\begin{array}{l}\text { - Conventional Hydrogen Bond } \\
\text { - Carbon Hydrogen Bond } \\
\text { - Van der Waals Bond } \\
\text { - Alkil }\end{array}$ \\
\hline 7. & Beta-sitosterol & -6.6 & $\begin{array}{l}\text { - VAL316, LEU489, MET490, } \\
\text { LEU495 \& ARG503 } \\
\text { - ALA493 }\end{array}$ & $\begin{array}{l}\text { - Van der Waals Bond } \\
\text { - Alkil }\end{array}$ \\
\hline 8. & Schleicherastatin 7 & -6.6 & - PRO324 \& ILE326 & - Alkil \\
\hline 9. & Schleicherastatin 2 & -6.5 & $\begin{array}{l}\text { - MET427, ALA430, THR431, } \\
\text { GLN506, SER512 \& ILE514 } \\
\text { - ILE510 } \\
\text { - ARG434, LEU509 \& MET517 }\end{array}$ & $\begin{array}{l}\text { - Van der Waals Bond } \\
\text { - Unfavorable Acceptor-Acceptor } \\
\text { - Alkil }\end{array}$ \\
\hline 10. & Schleicherastatin 4 & -6.5 & $\begin{array}{l}\text { - } \text { LEU320, LEU489, MET490 \& } \\
\text { LEU495 } \\
\text { - VAL316 \& ALA493 } \\
\end{array}$ & $\begin{array}{l}\text { - Van der Waals Bond } \\
\text { - Alkil }\end{array}$ \\
\hline 11. & Scopoletin & -6.3 & $\begin{array}{l}\text { - SER518, GLU523 \& TYR526 } \\
\text { - ASN519, GLY521 \& LYS529 } \\
\text { - TRP383, LEU384 \& LEU525 }\end{array}$ & $\begin{array}{l}\text { - Conventional Hydrogen Bond } \\
\text { - Van der Waals Bond } \\
\text { - Alkil }\end{array}$ \\
\hline 12. & Schleicherastatin 3 & -6.2 & $\begin{array}{l}\text { - HIS550 \& LYS362 } \\
\text { - ARG548 \& LEU370 } \\
\text { - GLN375 } \\
\text { - LEU372 \& ALA551 }\end{array}$ & $\begin{array}{l}\text { - Conventional Hydrogen Bond } \\
\text { - Van der Waals Bond } \\
\text { - Unfavorable Acceptor-Acceptor } \\
\text { - Alkil }\end{array}$ \\
\hline 13. & Schleicherastatin 1 & -6.2 & $\begin{array}{l}\text { - HIS476 } \\
\text { - THR483 } \\
\text { - GLU385 \& LEU508 } \\
\text { - ASP480 } \\
\text { - LEU479, LEU511 \& ARG515 }\end{array}$ & $\begin{array}{l}\text { - Conventional Hydrogen Bond } \\
\text { - Carbon Hydrogen Bond } \\
\text { - Van der Waals Bond } \\
\text { - Unfavorable Acceptor-Acceptor } \\
\text { - Alkil }\end{array}$ \\
\hline 14. & Schleicherastatin 6 & -6.1 & $\begin{array}{l}\text { - THR485 } \\
\text { - ILE487 \& HIS488 } \\
\text { - LYS481 \& ALA491 } \\
\end{array}$ & $\begin{array}{l}\text { - Conventional Hydrogen Bond } \\
\text { - Van der Waals Bond } \\
\text { - Alkil }\end{array}$ \\
\hline 15. & Schleicherastatin 5 & -5.9 & $\begin{array}{l}\text { - GLU330, ASN407 \& ARG352 } \\
\text { - LEU327 \& PRO333 } \\
\text { - TYR328 }\end{array}$ & $\begin{array}{l}\text { - Van der Waals Bond } \\
\text { - Alkil } \\
\text { - Pi-Sigma }\end{array}$ \\
\hline 16. & Schleicheol 2 & -5.5 & $\begin{array}{l}\text { - GLN375 \& ARG548 } \\
\text { - LEU370, THR371 \& LEU372 } \\
\text { - VAL368 }\end{array}$ & $\begin{array}{l}\text { - Conventional Hydrogen Bond } \\
\text { - Van der Waals Bond } \\
\text { - Alkil }\end{array}$ \\
\hline
\end{tabular}


Schleicherastatin 3 forms bonds with six amino acid residues. The bonds formed are conventional hydrogen bonds with the amino acids LYS362 and HIS550. Van der Waals bonds with LEU370, ARG548 and GLN375 and alkyl interactions with LEU372 through hydrophobic bonds. There is also an unfortunate bond with GLN375. The binding affinity value obtained is $-6.5 \mathrm{kcal} / \mathrm{mol}$.

Schleicherastatin 1 forms bonds with eight amino acid residues. The bonds formed are conventional hydrogen bonds with amino acid HIS476 and carbonhydrogen bonds with THR483. Van der Waals bonds with GLU385 and LEU508 and alkyl interactions with LEU479, LEU511 and ARG515 through hydrophobic bonds. There is also an unfortunate bond with the ASP480. The binding affinity value obtained is $-6.2 \mathrm{kcal} / \mathrm{mol}$.

Schleicherastatin 6 forms bonds with five amino acid residues. The bond formed is a conventional hydrogen bond with the amino acid THR485. Van der Waals bonds with ILE487 and HIS488 and alkyl interactions with LIS481 and ALA491 through hydrophobic bonds. The binding affinity value obtained is $-6.1 \mathrm{kcal} / \mathrm{mol}$.

Schleicherastatin 5 forms bonds with four amino acid residues. The bonds formed are van der Waals bonds with GLU330, ARG352 and ASN407 and alkyl interactions with LEU327 and PRO333 through hydrophobic bonds. And the Pi-sigma bond with the TYR328. The binding affinity value obtained is -5.9 $\mathrm{kcal} / \mathrm{mol}$.

Schleicheol 2 forms bonds with six amino acid residues. The bonds formed are conventional hydrogen bonds with GLN375 and ARG548. The van der Waals bond with LEU370, THR371, and LEU372 and the interaction between alkyl and VAL368 through hydrophobic bonds. The binding affinity value obtained was $-5.5 \mathrm{kcal} / \mathrm{mol}$. Several compounds have interactions with the same amino acid residues as the original ligands. These compounds are Lupeol acetate, Schleicheol 1 and Scopoletin against TRP383, LEU384, and GLY521. Based on the Lipinski test, ADME toxicity and docking results showed that lupeol and lupeol acetate was the best active compounds and had the lowest binding affinity value $-8.3 \mathrm{kcal} / \mathrm{mol}$. However, it is still lower than 4 hydroxyboxifen as one of the first-line therapies for ER+ breast cancer. Besides that, lupeol and lupeol acetate also fulfill the Lipinski, ADME, and Toxicity test criteria.

Table 4. Summary of Lipinski Test, ADME, Toxicity and Molecular Docking Results of Fifteen Active Compounds that qualify as candidates for Breast Cancer Drugs

\begin{tabular}{lllllcccc}
\hline No & Active Compound & Lipinski & Absorption & Distribution & Metabolism & Excretion & $\begin{array}{c}\text { Toxicity } \\
\text { Class }\end{array}$ & $\begin{array}{c}\text { Binding } \\
\text { Affinity } \\
\text { (kkal/mol) }\end{array}$ \\
\hline 1 & $\begin{array}{l}4- \\
\text { Hydroxytamoxyfen }\end{array}$ & Yes & High & No & Yes & Yes & 5 & -9.3 \\
2 & Scopoletin & & & & & & \\
3 & Beta-Sitosterol & Yes & High & No & Yes & Yes & 4 & -6.3 \\
4 & Betulin & Yes & High & Yes & Yes & Yes & 5 & -6.6 \\
5 & Betulinic Acid & Yes & High & No & Yes & Yes & 5 & -6.7 \\
6 & Lupeol & Yes & High & Yes & Yes & Yes & 5 & -7.1 \\
7 & Lupeol asetat & Yes & High & Yes & Yes & Yes & 5 & -8.3 \\
8 & Schleicheol 1 & Yes & High & Yes & Yes & Yes & 5 & -8.3 \\
9 & Schleicheol 2 & Yes & High & Yes & Yes & Yes & 5 & -5.1 \\
10 & Schleicherastatin 1 & Yes & High & No & Yes & Yes & 5 & -6.2 \\
11 & Schleicherastatin 2 & Yes & High & No & Yes & Yes & 5 & -6.5 \\
12 & Schleicherastatin 3 & Yes & High & No & Yes & Yes & 5 & -6.2 \\
13 & Schleicherastatin 4 & Yes & High & No & Yes & Yes & 5 & -6.5 \\
14 & Schleicherastatin 5 & Yes & High & No & Yes & Yes & 5 & -5.9 \\
15 & Schleicherastatin 6 & Yes & High & No & Yes & Yes & 5 & -6.1 \\
16 & Schleicherastatin 7 & Yes & High & No & Yes & Yes & 5 & -6.6 \\
\hline
\end{tabular}

\section{CONCLUSION}

Lupeol and lupeol acetate are the active compounds that pass the test based on the Lipinski rule, ADME, and toxicity. Besides, Lupeol and lupeol acetate proved low binding affinity value closest to the control ligand. Therefore, Schleichera oleosa may have potential as an inhibitor of alpha estrogen receptors. The inhibitory activity of alpha estrogen receptors has led to breakthroughs in plant-based medicinal products, particularly breast cancer.

\section{ACKNOWLEDGEMENTS}

We send our regards to our institution, especially to the Biology Department of Malang Islamic 
University, which has provided our facilities and infrastructure to complete this research.

\section{REFERENCES}

1. Athar M, Lone MY, Jha PC. First protein drug target's appraisal of lead-likeness descriptors to unfold the intervening chemical space. Journal of Molecular Graphics and Modelling. 2017. 72: 272-282.

2. Chander, S., Tang, C.R., Al-Maqtari, H.M., Jamalis, J., Penta, A., Hadda, T.B., Sirat, H.M., Zheng, Y.T., Sankaranarayanan, M. Synthesis and Study of Anti-HIV-1 RT Activity of 5-Bezoyl4-Methyl-1,3,4,5-tetrahydro-2h-1,5-

benzodiazepin-2-one Derivatives. Bioorg Chem. 2017. 72:74-79.

3. Chillistone, S and Hardman, J. Factor Affecting Drug Absorbtion and Distribution Anaesthesia and Intensive Care Medicine. 2008. Vol 9, No. 4.

4. Choy Y, Bin, Prausnitz MR. The rule of five for non-oral routes of drug delivery: ophthalmic, inhalation, and transdermal. Pharmaceutical Research. 2011. 28(5): 943-948.

5. Haris, M.F. Uji Sitotoksik, Toksisitas dan prediksi Fisikokimia Senyawa Isoliquititigenin dan Oxyresveratrol terhadap Reseptor B-Cell Lymphoma 2 (4AQ3) dan Vascular Endothelial Growth Factor Receptor-2 (2RL5) sebagai Terapi Kanker Serviks secara In Silico. Jurusan Farmasi, Fakultas Kedokteran dan Ilmu Kesehatan, UIN Maulana Malik Ibrahim Malang. 2019.

6. International Agency for Research on Cancer
(IARC) and World Health Organization. The Global Cancer Observatory. 2020. (https://gco.iarc.fr/today/data/factsheets/populatio ns/900-world-fact-sheets.pdf). Diakses pada tanggal 08 Mei 2020.

7. Liao, X.H., Lu, D.L., Wang, N., Liu, L.Y., Wang, Y., Li, Y.Q. Estrogen Receptor a Mediates Proliferation of Breast Cancer MCF-7 Cells via a p21/PCNA/E2F1-dependent Pathway. The FEBS Journal. 2014. 281 (2014), 927-942.

8. Lipinski CA, Lombardo F, Dominy BW, Feeney PJ. Experimental and Computational Approaches to Estimate Solubility and Permeability in Drug Discovery and Develop ment Settings. Adv Drug Deliv Rev. 1997. 23:3-25.

9. Meshram, N., M. Ojha, A. Singh, A. Alexander dan M. Sharma. Significance and traditional medicinal properties of Schleichera oleosa. Asian Journal of Pharmaceutical Research. 2015. 5(1): 61-64.

10. Patrick, Graham L. An Introduction to Medicinal Chemistry Fourth Edition. 2009. New York: Oxford University Press Inc.

11. Payne SJ, Bowen RL, Jones JL, Wells CA. Predictive markers in breast cancer- the present. Histopathology. 2008. 52(1):82-90.

12. Pires DEV, Blundell TL, and Ascher DB. pkCSM predicting small-molecule pharmacokinetic and toxicity properties using graph-based signature. Journal of Medicinal Chemistry. 2015. 58 :406672. 